\title{
Sacamuelas que queria concluir con la herramienta de una boca
}

\author{
$¡ O h !$ tu que comes con ajenas muelas \\ Mascando con los dientas que no mascas \\ $\mathrm{Y}$ con los dedos gomias y tarascas \\ Las encías pellizcas y repelas; \\ Tu que los mordiscones desconsuelas \\ Pues en las mismas sopas los atascas \\ Cuando en el mijagon corren borrascas \\ Las quijadas que dejas bisabuelas, \\ Por ti reta las bocas la corteza, \\ Revienta la avellana del valiente: \\ ¡Y su cáscara ostenta fortaleza! \\ Quitarnos el dolor, quitando el diente \\ Es quitar el dolor de la cabeza \\ ¡Quitando la cabeza que lo siente!
}

FRANCISCO DE QUEVEDO 